University of Nebraska - Lincoln

DigitalCommons@University of Nebraska - Lincoln

Entomology Papers from Other Sources

Entomology Collections, Miscellaneous

1988

Descriptions of Pupae of South American Robber Flies (Diptera:

Asilidae)

D. Steve Dennisi

Englewood, Colorado

Lloyd Knutson

USDA-ARS

Follow this and additional works at: https://digitalcommons.unl.edu/entomologyother

Part of the Entomology Commons

Dennisi, D. Steve and Knutson, Lloyd, "Descriptions of Pupae of South American Robber Flies (Diptera: Asilidae)" (1988). Entomology Papers from Other Sources. 59.

https://digitalcommons.unl.edu/entomologyother/59

This Article is brought to you for free and open access by the Entomology Collections, Miscellaneous at DigitalCommons@University of Nebraska - Lincoln. It has been accepted for inclusion in Entomology Papers from Other Sources by an authorized administrator of DigitalCommons@University of Nebraska - Lincoln. 


\title{
Descriptions of Pupae of South American Robber Flies (Diptera: Asilidae)
}

\author{
D. STEVE DENNIS ${ }^{1}$ AND LLOYD KNUTSON ${ }^{2}$
}

\begin{abstract}
Ann. Entomol. Soc. Am. 81(6): 851-864 (1988)
ABSTRACT The pupae of four South American species of robber flies, Diogmites vulgaris Carrera, Mallophora ruficauda (Wiedemann), Mallophora sylverii Macquart, and Triorla striola $(\mathbf{F}$.), are described and illustrated. The pupae of these species are compared morphologically with those of North American species of the same genera. A key to pupae of Asilidae at the subfamily level is provided. Biological notes associated with the specimens examined and with those of Pseudorus distendens (Wiedemann) indicate that the larvae prey upon immature stages of Scarabaeidae (Dyscinetus rugifrons LeConte for $D$. vulgaris and M. sylverii, Cyclocephala signaticollis Burmeister for M. ruficauda, and a cerambycid beetle for $P$. distendens). The notes also provide information on habitat, phenology, and duration of immature stages.
\end{abstract}

KEY WORDS Insecta, taxonomy, systematics, biology, classification

MORE THAN 1,000 SPECIES and 165 genera of robber flies have been described from the Americas south of the United States (Martin \& Papavero 1970). Although probably at least that many species remain to be described, information has been published on the pupae of only four neotropical species. In a study of the life cycle of Mallophora ruficauda (Wiedemann) (subfamily Asilinae) in Argentina, Copello (1927, 1942) included a description and photographs of the pupa. Clements \& Bennett (1969) described and illustrated the pupa of $\mathrm{Mal}$ lophora media Clements \& Bennett. Artigas (1970) presented a diagrammatic sketch of the lateral view of the opened pupal case of Eccritosa rubriventris (Macquart) (subfamily Asilinae) from Chile. Knutson (1976) described and illustrated in detail the pupa of Pseudorus distendens (Wiedemann) (subfamily Dasypogoninae) from Brazil under the synonym Doryclus distendens.

This study describes and illustrates for the first time the pupae of Diogmites vulgaris Carrera (Dasypogoninae), Mallophora sylverii Macquart, and Triorla striola (F.) (Asilinae). The pupa of $M$. ruficauda is redescribed and illustrated. The descriptions are based on examinations of specimens in the U.S. National Museum of Natural History (USNM), Washington.

Biological information (hosts, habitat, phenology, and duration of immature stages) is presented for $D$. vulgaris, $M$. sylverii, $M$. ruficauda, and $P$. distendens. This information has been taken from biological notes and voucher specimens from field and laboratory studies conducted in 1941-1943 by the USDA South American Parasite Laboratory in

5875 East Weaver Circle, Englewood, Colo. 80111.

${ }^{2}$ Systematic Entomology Laboratory, USDA-ARS, Beltsville, Md. 20705
Montevideo, Uruguay. The notes and a few voucher specimens are in the USDA European Parasite Laboratory in Behoust, France, and most of the voucher specimens are at USNM.

The larvae of D. vulgaris and $M$. sylverii are reported to consume pupae of Dyscinetus rugifrons (LeConte) (Scarabaeidae: Dynastinae), and larvae of $M$. ruficauda feed on the larvae of $C y$ clocephala signaticollis Burmeister (Scarabaeidae).

Additional biological information is provided for $P$. distendens because it was not presented by Knutson (1976) and because it supports the theory that many asilid larvae are primarily predaceous on immature stages of other insects.

The immature stages of only about $2 \%$ of the 5,000 described species of Asilidae are known (Knutson 1972). Even for species for which morphological information on the pupae exists, comparative information among genera and species in a subfamily is scant. Therefore, we include a discussion of the significant morphological characteristics of the pupae described in this paper and of the pupae of related species from the United States. In addition, we provide a key to the subfamilies of Asilidae on the basis of characters of the pupae.

\section{Descriptions of Pupae \\ Subfamily Dasypogoninae \\ Tribe Dasypogonini \\ Genus Diogmites Loew}

Malloch (1915) described and figured the pupa of "Deromyia winthemi Wiedemann" from two reared specimens from Illinois. Because Diogmites winthemi is a Neotropical species (Brazil and Colombia), we examined Malloch's adult specimens (in the Illinois Natural History Museum); they ap-

This article is a U.S. government work, and is not subject to copyright in the United States. 

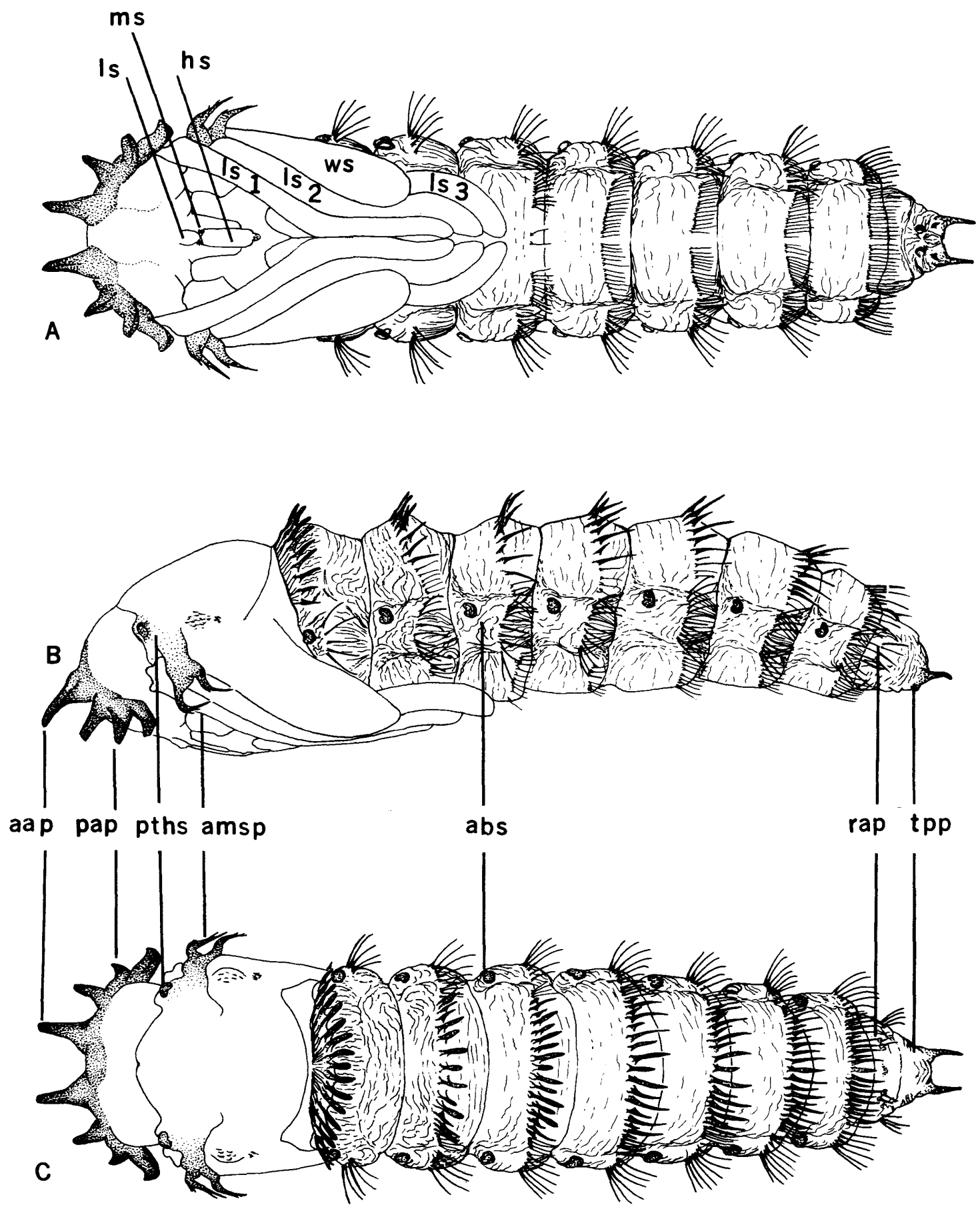

Fig. 1. Pupa of male D. vulgaris Carrera. (A) Ventral. (B) Lateral. (C) Dorsal. aap, anterior antennal process; abs, abdominal spiracles; amsp, anterior mesothoracic spines; hs, hypopharyngeal sheath; ls, labral sheath; ls 1 , leg sheath 1 ; ls 2 , leg sheath 2 ; ls 3 , leg sheath 3 ; ms, maxillary sheath; pap, posterior antennal processes; pths, prothoracic spiracle; rap, ringlike anterior portion, eighth abdominal segment; tpp, tapered posterior portion, eighth abdominal segment; ws, wing sheath.

pear to be $D$. misellus Loew. Malloch (1917) described and illustrated the pupa of Diogmites discolor Loew (Nearctic), and Bromley (1946) included $D$. discolor and D. misellus Loew in a key to the pupae of Asilidae of Connecticut. According to Martin \& Papavero (1970), 55 species of Diogmites are known from the Americas south of the United States. 


\section{Diogmites vulgaris Carrera Fig. 1}

Diogmites vulgaris is known only from Brazil (Minas Gerais, Mato Grosso, Goias, and São Paulo). In the USNM there are eight adults (five males, two females, one undetermined sex) pinned with pupal cases, five pupal cases (presumably two males, two females, and one damaged) pinned together, and nine apparently reared adults without pupal cases. All bear the following labels: "São Paulo, Braz, No. 802, Montevideo, So Amer Paras Lab, Host D[yscinetus] rugifrons, Parker, Berry, Silveira" (a line has been drawn through the last two names). Two adults with pupal cases bear the date "Jan. 10. 43." Two other adults with pupal cases bear the date "XII.26.42." The other labels lack dates. The specimen of undetermined sex is further labeled "Diogmites n. sp., HLP-Greene," "Blepharepium Gn. aff Deromyia CHTT." The host is a species of Scarabaeidae, subfamily Dynastinae. The reared adults of $D$. vulgaris compare well with paratypes of the species in the USNM.

Description. Subshining golden brown; spines and processes glistening reddish brown. Greatest length (including anterior antennal processes) male $17.0-19.0 \mathrm{~mm}$, female $15.0-18.0 \mathrm{~mm}$; greatest width of thorax, male and female $3.0-4.0 \mathrm{~mm}$; greatest width of abdomen male $3.0-4.0 \mathrm{~mm}$, female $3 \mathrm{~mm}$, tapering to $1.5-2.0 \mathrm{~mm}$ in male and female at greatest width of last abdominal segment.

Head with apical pair of long, dorsoventrally flattened, acuminate anterior antennal processes, not joined at base, separated at apices by length of one process; group of 3 basally joined, apically acuminate, posterior antennal processes located ventrolaterally on each side, 2 innermost processes straight, outermost process slightly elbowed basally, 2 outermost processes closer together and fused for a greater distance than others (thus appearing shorter than innermost process). Labral sheath without medial or apical keel, smooth to wrinkled around margins. Hypopharyngeal sheath smooth, with small callosity posteriorly. Maxillary sheaths smooth, extending slightly more than $1 / 2$ length of, and on either side of, hypopharyngeal sheath and with pair of weak medial tubercles at junction of labral and hypopharyngeal sheaths.

Anterior coxal sheaths smooth. Elongate, oval prothoracic spiracle on minute callosity, with slight anterior ridge, midlaterally at anterior margin of prothorax on each side. Pair of long, acuminate, flattened, recurved, anterior mesothoracic spines on each side of thorax above bases of second pair of leg sheaths, outer or anterior spine more strongly recurved than inner spine; outer margin of apical half smooth to serrate; basal area of cuticle surrounding spines slightly rugose. Posterior mesothoracic callosity slightly rugose, without posterior mesothoracic spine on lateral margin toward venter on each side; smaller callosity just posterior of posterior mesothoracic callosity. Wing sheaths only slightly rugulose, bent directly in front of first abdominal segment; each with pair of weak medial tubercles. Thoracic area posterodorsal to wing sheaths rugulose. Sheaths of hind pair of legs reaching to posterior margin of third abdominal segment.

Abdominal spiracles elongate oval, elevated above surface of pupal case and light reddish brown, situated along midline laterally. First abdominal segment with dorsal transverse row of 18-20 long, slightly recurved spines; 1 male case with 23 spines, including 3 bristlelike spines on left side, ventral surface down; most medial spines apically wide or spatulalike, some cases with medial or possibly dorsolateral bifurcate spines or both; medial spine shorter than surrounding spines, these becoming slightly shorter toward venter; dorsolateral spines in some cases alternately long and very short; dorsolateral bristles absent, 5-6 lateral bristles behind each spiracle, venter obscured. Segment 2 with medial transverse row of 13-15 alternately long and short spines and 4-6 dorsolateral bristles on each side. Segments 3-7 with transverse row of 10 17 alternately long and short spines and 3-6 dorsolateral bristles on each side. Segments 2-7 sometimes with bifurcate medial or dorsolateral spines; most lateral spines bristlelike, often difficult to distinguish from dorsolateral bristles; short spines generally becoming shorter toward dorsolateral surface but longer toward posterior; 9-12 lateral bristles behind each spiracle. Venter of segment 2 obscured by third pair of leg sheaths; venter of segment 3 with incomplete transverse row of about 20-22 bristles (some medial bristles presumably rubbed off by leg and wing sheaths); segments 4-7 with nearly complete transverse row of about $26-30$ subequal bristles; some bristles appearing fused basally or very close together; medial bristle on each side of midline sometimes shorter than surrounding bristles. Eighth abdominal segment composed of ringlike anterior portion with 2 pairs of widely separated, dorsal, bristlelike spines of subequal length on each side of midline (these difficult to see because of their light color); dorsolateral bristles absent, 4 lateral bristles on each side behind spiracle, ventral bristles and spines absent. Tapered posterior portion rugose, pair of short, straight to slightly recurved dorsolateral processes, pair of low ventrolateral thornlike tubercles; midventral or ventral tubercles absent in female but with pair of slight swellings almost touching one another; female with pair of large midventral tubercles distinctly separate from one another.

\section{Subfamily Asilinae Tribe Asilini Genus Triorla Parks}

Parks (1968) proposed the new genus Triorla for Efferia interrupta (Macquart) (Asilus) and Eicherax striola (F.) (Dasypogon), noting, "The genus Triorla has three long apical aedeagal tubes which 
separate it from Efferia Coquillett with a hookshaped aedeagus, and from Eicherax Bigot whose aedeagus has three short apical tubes." T. interrupta is a common and widespread species, ranging across the southern United States from California to South Carolina and south to Honduras (three males in USNM). T. striola ranges from Panama (Canal Zone) (two females in USNM) to Tucuman, Argentina (two males in USNM).

Adults of these two species are easily distinguished by differences in the terminalia of males and females, which Parks (1968) figured. The epandria of $T$. interrupta are deeply emarginate posteriorly, and the hypandrium lacks a posterior projection, whereas the epandrium of $T$. striola is barely emarginate and the hypandrium has a distinctive posterior projection. The sixth and seventh terga of $T$. interrupta males and females and of T. striola males are similar in having a triangular black median spot that usually does not attain the anterior margin. In $T$. striola females, the sixth tergite has a black, linear, median spot that attains the anterior margin. From dorsal view, the seventh tergite appears entirely black but, contrary to Parks' statement, a narrow stripe of grayish pruinosity runs along the lateral margin.

Davis (1919) and Osterberger (1930) observed that pupae of $T$. interrupta, under the synonyms Erax maculatus and Erax interruptus, respectively, occur in the soil. Under the synonym Erax maculatus, Malloch (1917) described the pupal case of a male and noted, "The larvae is predaceous upon white-grubs." The voucher specimens for the records cited above have not been examined.

\section{Triorla striola (Fabricius)}

Fig. 2A-C

Nothing has been published to date on the biology or immature stages of T. striola. The accompanying description is based on a pupal case in the USNM labeled "Bonito Prov., Pernambuco, Brazil, 8/1[18]83." This appears to be the pupal case of a female that is labeled identically and bears the additional label "Col. on Cotton." The female is teneral and somewhat shriveled, but the distinctive color pattern of the abdomen is well-developed. An additional male and 2 females in the USNM are labeled "Pernambuco, Brazil;" the male is dated " $2 / 183$ " and the females "January 4-83" and "8/1 83."

Description. Head and thorax subshining golden brown, abdomen yellowish tan; spines and processes glistening reddish brown, darker apically except for dorsal abdominal spines, these evenly colored along entire length; bristles yellowish brown. Greatest length (including anterior antennal processes) $17.0 \mathrm{~mm}$; greatest width of thorax $5.0 \mathrm{~mm}$; greatest width of abdomen $4.5 \mathrm{~mm}$, tapering to 2.0 $\mathrm{mm}$ at greatest width of last abdominal segment.

Head with apical pair of dorsally flattened, ventrally wedge-shaped anterior antennal processes not joined at base; group of 3 basally fused posterior antennal processes ventrolaterally on each side, 2 outermost processes of each group close together and fused for some distance, thus appearing shorter than innermost process; all 3 processes wide, apically rounded; base of outermost process flattened dorsad so outside of process not curved but almost perpendicular. Labral sheath slightly rugulose around swollen rugose apical keel. Hypopharyngeal sheath slightly rugose on either side of midline, 2 ridgelike swellings on either side of midline; 2 innermost swellings larger than outermost swellings and joining sides of medial, dorsally concave posterior tubercle. Maxillary sheaths rugose, especially on inner half, each with apically rounded process posteriorly.

Anterior coxal sheaths smooth to slightly rugulose, with medial split anteriorly on each side. Elongate-oval, raised, prothoracic spiracle situated midlaterally at anterior margin of prothorax on each side; slight ridge of sclerotized cuticle posteriorly toward venter at base of and anterior to spiracle. Pair of dorsoventrally flattened, short, wide, apically blunt to rounded anterior mesothoracic spines on each side of thorax above bases of sheaths of second pair of legs; posterior spine sometimes more curved on outer margin. Large, smooth to slightly rugulose, posterior mesothoracic callosity on each side with apically rounded posterior mesothoracic spine and two tubercles with sclerotized edges on posterior margin behind mesothoracic spine or toward dorsum; small sclerotized ridge toward anterior margin of callosity. Sheaths of first and second pair of legs each with medial tubercle on outer margin; sheaths of first pair of legs each with medial callosity and tubercle on each side of base of heart-shaped part below anterior coxal sheaths and toward apices of leg sheaths (posterior of medial tubercle). Wing sheaths irregularly rugulose on anterior half, rugose on posterior half; basal tubercle absent but with 2 medial tubercles, tubercle toward venter larger than other tubercle, apically rounded, concave on side toward dorsum. Thoracic area above wing sheaths irregularly rugulose. Sheaths of third pair of legs reaching to between posterior margin of third and middle of fourth abdominal segments.

Abdominal spiracles semiovate, slightly raised and reddish brown, along lateral midline. First abdominal segment with dorsal transverse row of 15 long, apically recurved spines, 1 short outer spine on each side, short spine on each side of pair of medial long spines; 2 medial dorsolateral bristles, 11 bristles behind each lateral spiracle, venter obscured. Segments 2-5 with medial transverse row of 6 long spines, between these 1-3 (usually 1 or 2) short spines (short spines slightly in front of long spines), and 3-6 dorsolateral short spines on each side (a few bifurcate). Segments 6-7 similar to 25 but with transverse row of alternate 6 long and 5 short bristles (short bristles usually single, but right side with pair of short spines between 2 out- 

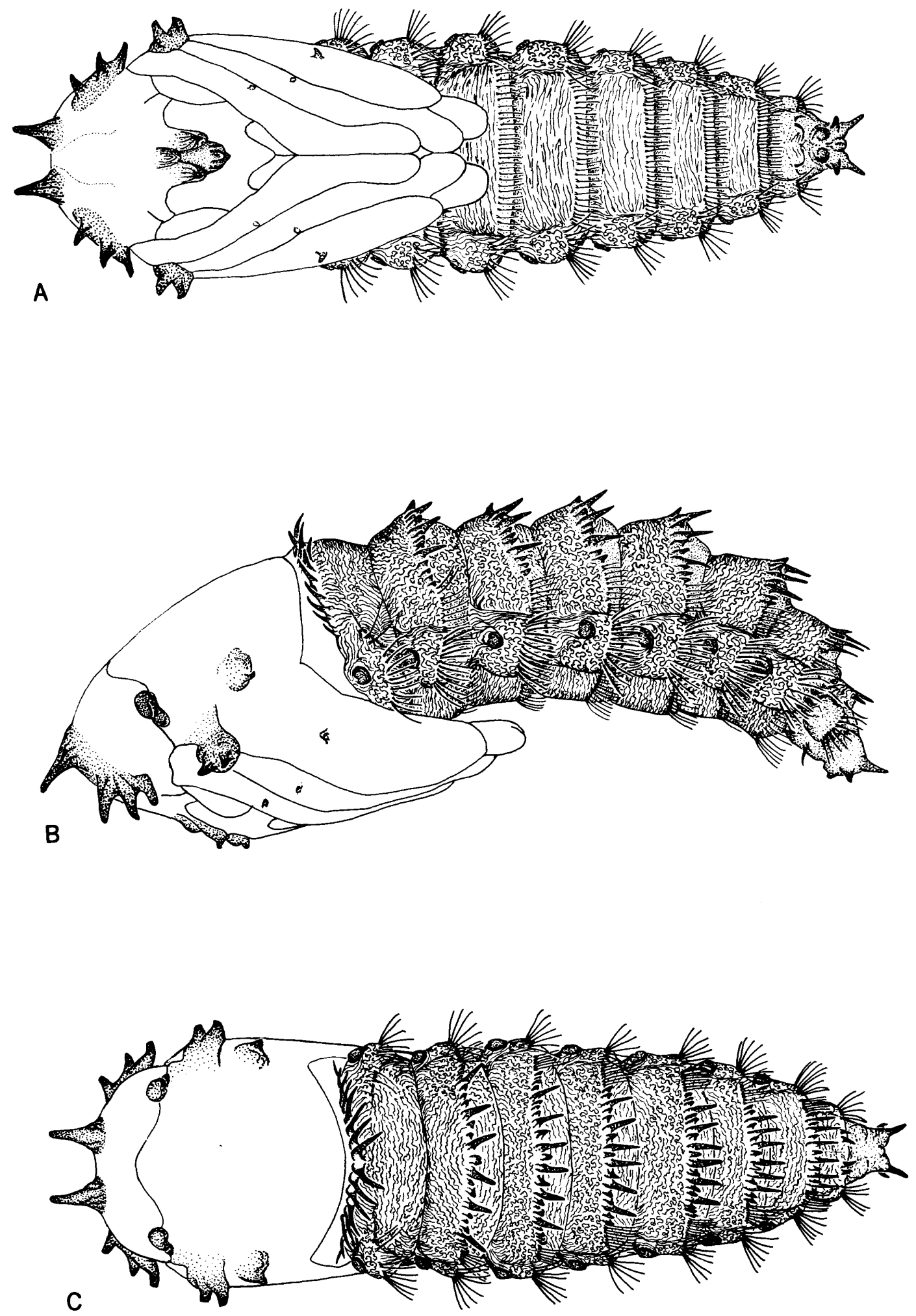

Fig. 2. Pupa of "female" T. striola. (F.). (A) Ventral. (B) Lateral. (C) Dorsal. 
ermost long spines), and 1-2 dorsolateral short spines. Segments 2-6 with 6-8 dorsolateral bristles on each side and 12-15 bristles behind each lateral spiracle; segment 7 with 3 or 4 dorsolateral bristles and 9 lateral bristles. Venter of segment 2 with 813 bristles on each side of and extending under sheaths of third pair of legs; segments 3-6 and 7 each with complete transverse row of 31-55 and 28 straight to apically recurved bristles, respectively; bristle on each side of middle bristle on segments 6 and 7 slightly posterior of surrounding bristles (thicker on segment 7); some bristles shorter than others. Eighth abdominal segment composed of ringlike anterior portion, with 2 dorsolateral spines (innermost spine larger than outermost spine) and 1-2 dorsolateral bristles on each side of midline; 8-9 lateral bristles on each side and 1-2 ventrolateral bristles (apically curved toward one another) on each side of midline. Tapered posterior portion with anterior dorsolateral tubercle on each side; pair of long, straight dorsolateral processes; pair of short, straight ventrolateral processes not fused basally to dorsolateral processes; and pair of basally fused and wide ventromedial processes; all processes on tapered portion rounded apically; midventral tubercles absent.

\section{Genus Mallophora Macquart}

The genus Mallophora is restricted to the Western Hemisphere, where it is most abundant in northern and central South America, especially across a broad area around the Tropic of Capricorn. In the most recent revision of the genus (Artigas \& Angulo 1980), 122 nominal species were reduced to 51 valid species.

\section{Mallophora sylverii Macquart}

Fig. 3A-C

In their revision of the genus Mallophora, Artigas \& Angulo (1980) synonymized antica Curran, affinis Schiner, ajax Curran, contraria Walker, geniculata Macquart, opposita Walker, scutellaris Lynch, and sexualis Curran under M. sylverii Macquart. They noted that the color of the adult vestiture in $M$. sylverii is highly variable. This is a common species distributed across a broad area of eastern and central South America (Bolivia, southern Brazil, Paraguay, Uruguay, and northern Argentina).

In the USNM there is one pupal case with a pinned male labeled "No. 802, Montevideo, So. Amer. Paras. Lab., Date Jan. 12, 43, host Dyscinetus rugifrons, Parker, São Paulo, Braz."

Description. Subshining golden brown, several abdominal segments (especially laterally and ventrally) with cupreous brown mottling on inside surface; spines and processes glistening reddish brown, darker apically. Greatest length (including anterior antennal processes) $21.0 \mathrm{~mm}$; greatest width of tho$\operatorname{rax} 6.0 \mathrm{~mm}$; greatest width of abdomen $5.0 \mathrm{~mm}$, tapering to $2.0 \mathrm{~mm}$ at greatest width of last abdominal segment.

Head with apical pair of dorsally flattened, ventrally wedge-shaped anterior antennal processes not joined at base; group of 3 basally fused, apically rounded, posterior antennal processes ventrolaterally on each side, 2 outermost processes of each group fused for some distance and closer together, thus appearing shorter than innermost process. Labral sheath with apical keel surrounded by dark sclerotized concentric rings, 3 ridges anteriorly. Hypopharyngeal sheath rugulose along midline, rugose on each side of midline and minute, basally concave tubercle posteriorly. Maxillary sheaths each with large apically rounded process, rugose basally, minute medial tubercle on each side of labral sheath.

Anterior coxal sheaths smooth with medial splits anteriorly on each side. Prothoracic spiracle on rugose area midlaterally at anterior margin of thorax on each side. Pair of broad, dorsoventrally flattened, apically blunt, anterior mesothoracic spines curved posteriorly on each side of thorax above base of sheaths of second pair of legs; posterior spine slightly longer and broader than anterior spine; thoracic area above spines rugose. Large posterior mesothoracic callosity at base of each wing sheath, minute posterior mesothoracic spine, and longitudinal ridges. Wing sheaths rugose on posterior $2 / 3$, large tubercle near base ("in front of" posterior mesothoracic callosity), 2 medial tubercles (innermost tubercle larger than outermost), and indistinct, circular, raised area posterior of medial tubercles. Thoracic area above wing sheaths mostly smooth except for rugosity around posterior mesothoracic callosity. Sheaths of third pair of legs reaching to between posterior margin of second abdominal and middle of third abdominal segments.

Abdominal spiracles C-shaped, buttonlike ring of thickened, shiny, reddish brown cuticle, along midline laterally. First abdominal segment with dorsal transverse row of 15 broad, arrowheadshaped, straight to apically recurved spines; outermost spine on right side and 2 medial spines very short; outermost spine on left side and several other spines much broader than other spines, with jagged apical edges; dorsolateral bristles absent, 3 broad bristles at side of lateral spiracles toward venter, venter obscured. Segments 2-4 with medial dorsal row of 12-14 fairly broad, alternate, short and long arrowhead-shaped spines; segments 5-7 similar but difference in size between short and long spines more pronounced and spines not so arrowheadshaped but rounder basally. Segments 2-7 with 35 basally fused, often bifurcate, dorsolateral bristles; 5-7 bristles behind each lateral spiracle, most bristles broad, but some segments (beginning with third bristle from dorsum) with alternate narrow and broad bristles, a few bristles bifurcate and fused basally. Venter of segment 2 with 5-6 medial bristles on each side of sheaths of third pair of legs, some bristles broad, basally fused or bifurcate or 

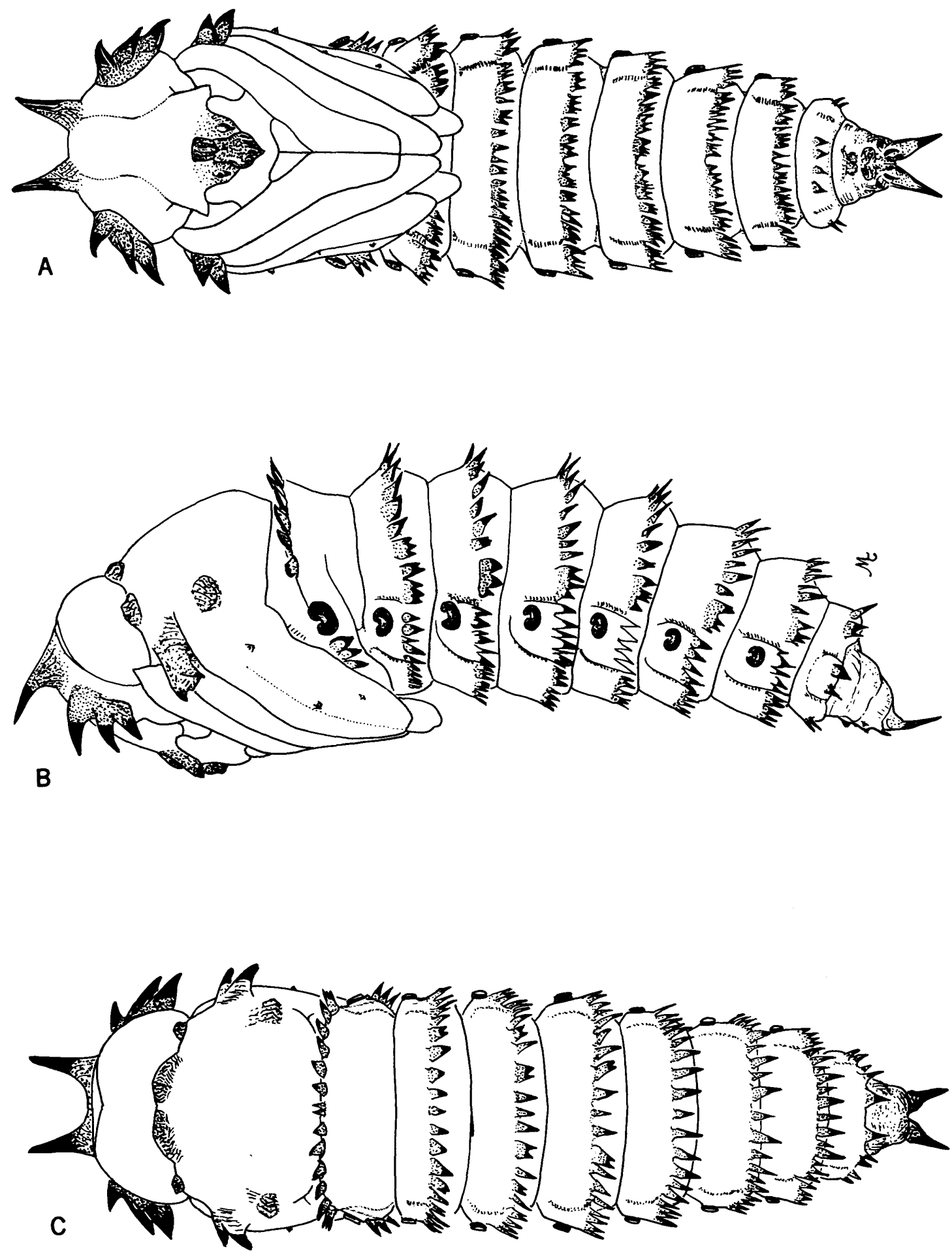

Fig. 3. Pupa of male M. sylverii Macquart. (A) Ventral. (B) Lateral. (C) Dorsal. Abdominal striations not shown. 
both. Segments 3-7 with 15-19 medial bristles; 35 ventrolateral bristles generally broader than other bristles, these and other bristles often basally fused or bifurcate or both; medial space on segments 36 more distinct than on segment 7. Eighth abdominal segment composed of ringlike anterior portion with 3 dorsolateral spines on each side of midline, outermost spine short, 2 innermost spines on right side basally close together but divergent apically; 2 or 3 lateral bristles, 2 bristles toward venter on right side fused basally; 4 ventral spines. Tapered posterior portion with pair of long, diverging, dorsolateral processes and pair of small ventrolateral processes fused basally to dorsolateral processes; venter of tapered portion with 1 tubercle on each side of ventrolateral processes, 2 medial tubercles anterior to aforementioned tubercles and 2 outer small tubercles anterior to these tubercles; 2 midventral tubercles anterior to other tubercles. In the pupal cases of other species of Mallophora, these tubercles are located at the posterior margin of the ringlike anterior portion or at the junction of the ringlike anterior and tapered posterior portions of the eighth abdominal segment.

\section{Mallophora ruficauda (Wiedemann) Fig. 4A-C}

Artigas \& Angulo (1980) placed Mallophora fulviventris Macquart, $M$. fulvianalis Macquart, $M$. pyrura Rondani, and $M$. soccata Thomas in synonomy with this species. The reared specimens mentioned herein compare well with specimens in the USNM identified by Artigas. The geographical distribution of this species is similar to that of $M$. sylverii but extends farther south into Argentina. It is one of the few South American species about which any biological information has been published (Copello 1927, 1942). The adults appear to be important predators of bees.

The pupa was briefly described by Copello (1927, 1942). A more detailed description and accompanying figures of the pupa follow. This description is based on six pupal cases associated with five females and 1 male in the USNM. The female cases are labeled, "So Amer. Par. Labo, No. 1013.1, XII20, Host Scarabaeidae, Uruguay nr Montevideo, P. A. Berry Col," "So Amer. Par. Labo, No. 1013.1, XII-26, Host Scarabaeidae, Uruguay nr Montevideo, P. A. Berry Col," "No. 561.8 Montevideo, So Amer. Par. Labo, XII-31, Host Scarabaeid, Parker and Silveira," "No. 561.9 Montevideo, So Amer. Par. Labo, XII-21, Host Scarabaeid, Parker and Silveira," "No. 626.2, Montevideo, So Amer. Par. Lab, XII-17, Host in soil, Silveira." The male case is labeled, "So Amer. Par. Labo, No. 1013.1, VII22, Host Scarabaeidae, Uruguay nr Montevideo, H. L. Parker Col."

Description. Subshining golden brown; several abdominal segments, leg, and wing sheaths often with pale yellowish to reddish brown mottling on inside; spines and processes glistening reddish brown, darker apically. Greatest length (including anterior antennal processes) male $23.0 \mathrm{~mm}$, female $21.0-25.0 \mathrm{~mm}$; greatest width of thorax male 6.5 $\mathrm{mm}$, female $6.0-7.0 \mathrm{~mm}$; greatest width of abdomen male $5.5 \mathrm{~mm}$, female $5.0-6.0 \mathrm{~mm}$, tapering to $2.0 \mathrm{~mm}$ (male) and $1.5-2.0 \mathrm{~mm}$ (female) at greatest width of last abdominal segment.

Head with apical pair of dorsally flattened, ventrally wedge-shaped anterior antennal processes not joined at base; group of 3 basally fused posterior antennal processes ventrolaterally on each side, 2 outermost processes fused basally for a greater distance and closer together, thus appearing shorter than innermost process (one female case has two innermost processes almost completely fused on left side [ventral side up]); outermost process elbowed basally; processes apically rounded to slightly acute. Labral sheath with median keel surrounded by 2-4 dark sclerotized rings; rugulose to rugose anteriorly. Hypopharyngeal sheath mostly smooth, rugose around small posterior tubercle on each side of midline (tubercle minute to almost absent in some specimens), and at base of larger medial posterior tubercle. Maxillary sheaths each with large, apically rounded posterior process, rugose about process and anteriorly; male case rugose medially on each side of labral sheath, minute tubercle on left side (ventral side up); female cases much smoother medially on each side of labral sheath, only one female case with minute tubercle on right side (ventral side up). Because of the variability between pupal cases of the same species of Asilidae, we assume that some cases of this species have medial spines on each side of the labral sheath.

Anterior coxal sheaths mostly smooth to slightly rugose anteriorly, with medial split anteriorly on each side. Prothoracic spiracle on very rugose area, situated midlaterally at anterior margin of thorax on each side. Pair of broadly flattened, subequal, anterior mesothoracic spines on each side of thorax above bases of sheaths of second pair of legs; anterior spine curved posteriorly and more apically acute on posterior margin, posterior spine straighter, medially acute; thoracic area above spines rugose. Large posterior mesothoracic callosity at base of each wing sheath; posterior mesothoracic spine minute to absent, often difficult to see because of rugosity and anterior-posterior ridges of callosity. Wing sheaths very rugose, especially toward apices, with large tubercle near base (in front of posterior mesothoracic spine), 2 medial tubercles (innermost tubercle larger than outermost), and small circular upraised area posterior of medial tubercles and more toward dorsal surface. Thoracic area above wing sheaths mostly smooth. Sheaths of third pair of legs reaching to middle of second or third abdominal segments or somewhere between these segments.

Abdominal spiracle a C-shaped, buttonlike ring of thickened, shiny, reddish brown cuticle, along midline laterally. First abdominal segment with dorsal transverse row of 14-16 apically recurved, 

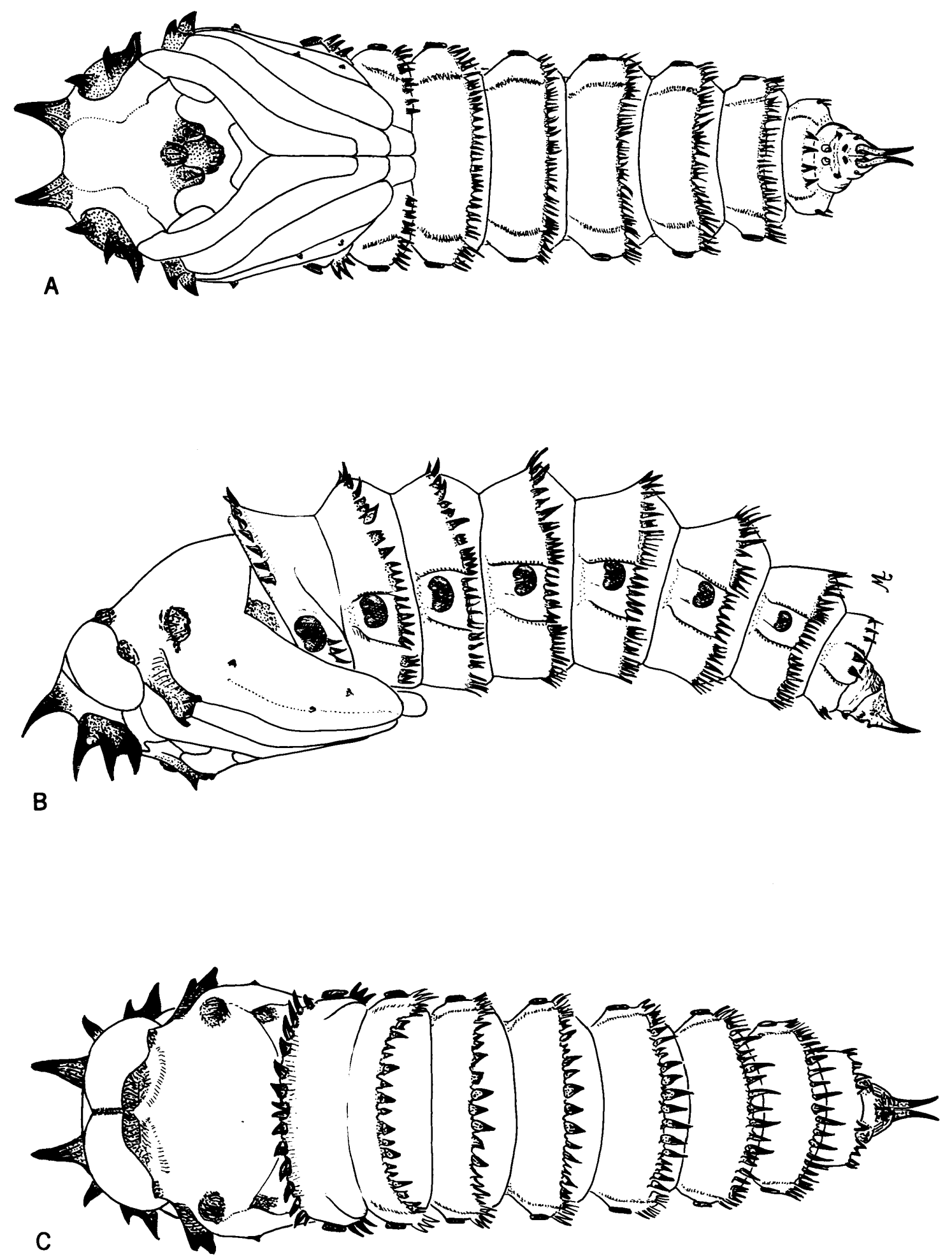

Fig. 4. Pupa of male M. ruficauda (Wiedemann). (A) Ventral. (B) Lateral. (C) Dorsal. Abdominal striations not shown. 
arrowhead-shaped spines along anterior margin; outermost spine on each side and two medial spines shorter than other spines; some spines bifurcate to trifurcate, third spine from midline on each side sometimes very broad and trifurcate or multifurcate apically; dorsolateral bristles absent, 3 bristles behind (or to side toward venter) of lateral spiracle, venter obscured. Segments 2-4 with medial dorsal row of 13-16 alternate, broad, short, straight, arrowhead-shaped, long and straight to apically recurved spines; broad spines of ten apically bifurcate or with many jagged teeth and slightly in front of arrowhead-shaped spines. Segments 5-7 with medial dorsal row of spines similar to those on segments 2-4, but all specimens more arrowheadshaped and short spines not so broad; short spines often bifurcate. Segments 2-7 with 4-7 dorsolateral bristles, these often basally fused (especially outermost bristles) and bifurcate; 7-10 often long and apically narrow bristles behind each lateral spiracle, many bristles bifurcate. Venter of segment 2 with 5-6 medial bristles on each side of sheaths of third pair of legs; segments 3-6 with medial row of 22-32 unequal bristles, segment 7 with 16-22 bristles; male bristles in complete transverse row, female bristles separated by medial space (on some cases this space is indistinct or has a very short medial bristle on segment 3); bristles, especially outer 3-4, often fused basally; many bristles bifurcate. Eighth abdominal segment composed of ringlike anterior portion with 3 dorsolateral spines (in a few cases 2 , or 2 on one side and 3 on other), outermost spine shorter than other 2 spines and often bifurcate; 2-3 lateral bristles on each side; venter of male with 4 spines in transverse row, females usually lack spines but may have 1 medial spine or spinelike tubercle on each side of midline. Tapered posterior portion with pair of long dorsolateral processes curved outwards and pair of small ventrolateral processes basally fused to dorsolateral processes; venter of tapered portion with 2 medial tubercles and 2 outer tubercles slightly anterior of medial tubercles; 2 medial, apically rounded tubercles on posterior margin of ringlike anterior portion (in male pupa these tubercles larger and farther apart than in female).

\section{Subfamily Dasypogoninae Tribe Megapodini, Subtribe Megapodina Pseudorus distendens (W/iedemann)}

The pupa of $P$. distendens was described and figured by Knutson (1976) as Doryclus distendens. Papavero (1975) synonymized Doryclus Jaennicke 1867, along with Ampyx Walker 1855 and Pseudoryclus Carrera 1953, under Pseudorus Walker 1851, and noted:

This extremely difficult group, highly variable in color and size, has always baffled the dipterists. . . I am here considering, provisionally, only two species in this group-distendens and mexicanus; the first seems to be an exclusively forest-dwelling species (see Map); mexicanus Bromley is here considered a species because it inhabits the Sonoran Desert; however, it cannot be adequately separated morphologically from distendens.

Papavero's (1975) distribution map shows $P$. distendens ranging from central coastal Mexico to near Buenos Aires, Argentina.

\section{Biological Information}

Many asilid larvae are predaceous on the immature stages of other insects (Knutson 1972; Lavigne et al. 1978). The information from the South American Parasite Laboratory supports this observation for the larvae of $D$. vulgaris, $M$. sylverii, and $M$. ruficauda. In their host-parasite and parasite-host lists of insects reared in the South American Parasite Laboratory during the period 194046, Parker et al. (1953) included "Blepharepium sp., Deromyia sp., Diogmites sp. nov., Mallophora freycinetti Macq., Mallophora sp. (Asilidae) and Psilocephala sp. (aff. scutellaris Loew) (Therevidae)" under "Dyscinetus rugifrons (Burm.)," with the comment, "All predators on grub. Itaquaquecetuba, Brazil."

The pupa of Pseudorus distendens was described by Knutson (1976). However, the detailed label data were not given by Knutson (1976) for the reared specimens of $P$. distendens in the USNM because they had been summarized by Papavero (1975). The label data indicate that the host of the larvae is a cerambycid beetle. The complete label data are as follows: Ten specimens are labeled, "Zetek \# 1689; Panama, Parita; J. Zetek Collector." One adult, partially emerged from a pupal case, bears a label, "Doryclus distendens Wd., det. Aldrich." Two pupal cases without adults are not labeled further. One female is further labeled, " $E x$ orista No. 23," "In cerambycid Borer holes in Orange tree, 4-27-1922. Zetek." Two females are further labeled, "Bred from Orange Tree." Eleven specimens are labeled, "Z-3224." Two pupal cases bear no additional labels and one is further labeled, "A. E. Pritchard Collection 1962." The rest of the specimens (4 males, 4 females) each bear three additional labels as follows: "on Triplaris americana," "Summit, C. Z., emerged Mar--June 1930," "J Zetek Collector." One female is labeled, "Doryclus distendens Walk, det. 1940, A. E. Pritchard; A. E. Pritchard Collection 1962," and two males bear the Pritchard Collection label. Triplaris americana L. is a tree, a member of the Polygonaceae.

The pupal stage of Asilidae has been recorded as lasting from 1 to $2 \mathrm{wk}$ (Skidmore 1960) to about $7 \mathrm{wk}$ (Melin 1923). The biological notes from the South American Parasite Laboratory show that the pupal stage of $M$. ruficauda lasts 2-4 wk. Accurate records were not kept for $D$. vulgaris and $M$. syl- 
Table 1. Morphological differences between pupae in the genera Triorla and Mallophora (subfamily Asilinae)

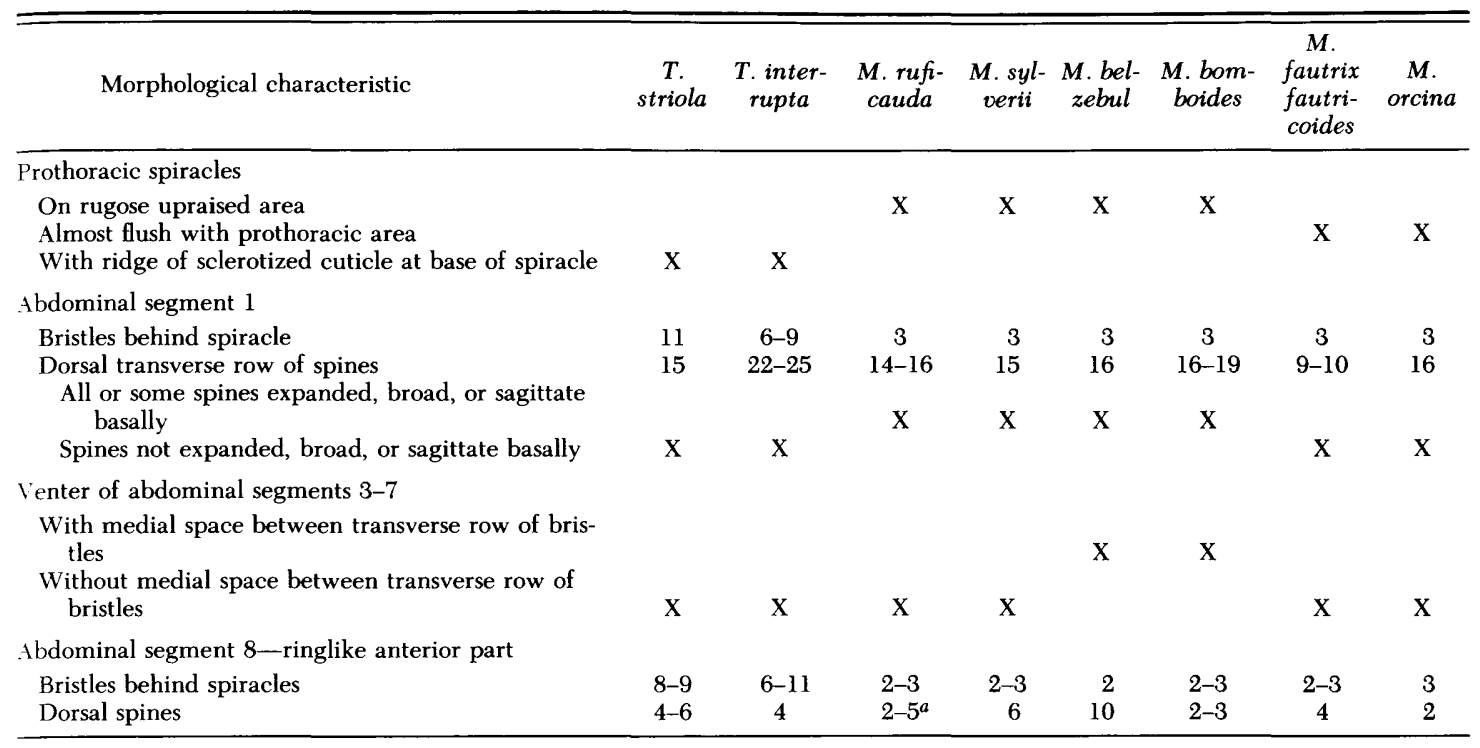

a Usually 3.

verii, but their pupal stage apparently lasts $9-10$ wk.

Because so little information has been published on the immatures of Asilidae, detailed notes from the South American Parasite Laboratory are summarized here.

Biological Notes from South American Parasite Laboratory. Larval Specimens No. 561.8, 561.9, 561.11. On 23 October 1941, an undetermined number of larvae of the scarabaeid Cyclocephala signaticollis Burmeister (determined by C. S. Carbonell) was collected at "La Pedrena Canelones" near Montevideo, Uruguay. On 2 December, two larvae (No. 561.8 and 561.9) were observed to be parasitized by one dipterous larva each. The dipterous larvae formed pupal cases on 13 December. One adult emerged on 29 December, and the other emerged on 7 January 1942. An asilid iarva (No. 561.11) (specimen not seen and not identified in the notes but probably $\boldsymbol{M}$. ruficauda) was collected with the above, formed a pupal case on 19 December, and the adult emerged 16 January 1942. No. 626.2. A larva found in soil on 5 November 1941 formed a pupal case on 24 November, and an adult M. ruficauda emerged on 17 December. No. 1013.1. The biological notes labeled 1013 start as follows: "V.-14-45-Colonia Valdence-Perrone brought in 130 larvae or grubs from the field. These were obtained by following the plow and picking up the larvae as they were unearthed. These collections represent a week's work." Part of the rearing notes are not entirely clear, and some notes may be missing. The notes for 1013.1 and 1013.3-1013.6 show that collections of 846 "white grubs" also were made on 6 and 9 June at Melilla, Pedera, and Pondo, Uruguay. The information on 1013.1 con- tinues on 25 October, with the note that one grub larva has an external parasite larva on it. On 7 November, it was noted that this "Diptera (Asilid) larva is full grown having devoured grub." The larva formed a pupal case on 15 November, and the adult emerged 19 December.

Biological Notes from South American Parasite Laboratory. No. 802. These notes pertain to a mixed collection of D. vulgaris and M. sylverii. Of 117 asilid pupae collected on 10 and 22 November and 5 and 18 December 1942 at Itaquaquecetuba, near Montevideo, Uruguay, 41 died by 26 December 1942. Adults emerged from the remaining pupal cases between 10 January and 24 February (mostly between 25 and 30 January). The notes state that these are "Mallophora (determined by C. H. T. Townsend) and Blepharepium vel (sic) gn off. Deromyia." The notes state that "They are pred[ators] of the Dyscinetus rugifrons pupa."

In addition to this information on $M$. sylverii, there is one adult female in the USNM that is labeled, "Larva predator on pupa of Dyscinetus rugifrons. \#802. See adults."

\section{Comparative Morphology of Pupae of Asilidae}

The taxonomy of South American robber flies and of the family Asilidae in general is based entirely on the morphology of adults. To provide information for the development of additional character systems for robber fly taxonomy, we have compared the pupae of the genera and species of the two subfamilies of robber flies described in this paper with those of related species íound primarily in the United States. In Table 1, we compare major 
Table 2. Morphological differences between pupae in the genus Diogmites (subfamily Dasypogoninae)

\begin{tabular}{|c|c|c|c|c|}
\hline Morphological characteristic & $\begin{array}{c}D . \\
\text { vulgaris }\end{array}$ & $\begin{array}{c}D . \\
\text { bilineatus }\end{array}$ & $\begin{array}{c}D . \\
\text { discolor }^{a}\end{array}$ & D. winthemi \\
\hline \multicolumn{5}{|l|}{ Abdominal segments $3-7$ ventrally } \\
\hline \multicolumn{5}{|l|}{ Labral sheath } \\
\hline $\begin{array}{l}\text { With slight posterior callosity } \\
\text { Without posterior callosity }\end{array}$ & $\mathrm{X}$ & $\mathrm{X}$ & $\mathrm{X}$ & $\mathrm{X}$ \\
\hline \multicolumn{5}{|l|}{ Abdominal segment 1} \\
\hline $\begin{array}{l}\text { Number of spines } \\
\text { Medial spines apically wide or spatulalike } \\
\text { Medial spines not apically wide or spatulalike }\end{array}$ & $\begin{array}{l}19 \\
X\end{array}$ & $\begin{array}{l}19 \\
\mathrm{X}\end{array}$ & 27 & $\begin{array}{l}27 \\
\mathrm{X}\end{array}$ \\
\hline \multicolumn{5}{|l|}{ Abdominal segment 8} \\
\hline
\end{tabular}

${ }^{a}$ The morphology of $D$. discolor is based on information in Malloch (1917) and Bromley (1946).

morphological characteristics of the pupae of $M$. ruficauda and $M$. sylverii (subfamily Asilinae) with those of four species from the United States $(M$. belzebul Schiner, M. bomboides (Wiedemann), $M$. fautrix fautricoides Curran, and $M$. orcina (Wiedemann)). In Table 1, we include the pupa of $T$. striola described in this paper and that of $T$. interrupta (Macquart). According to Martin \& $\mathrm{Pa}$ pavero (1970), T. interrupta is reported to occur in the United States, Mexico, and Central America (Guatemala and Honduras). In Table 2, we compare the pupa of Diogmites vulgaris (subfamily Dasypogoninae) with the pupae of three species of Diogmites found in the United States $(D$. discolor Loew, D. winthemi Wiedemann, and D. bilineatus Loew).

Complete descriptions and illustrations of the pupae of the aforementioned species of $\mathrm{Mal}$ lophora, Triorla, and Diogmites from the United States are in preparation.

Tables 1 and 2 show that genera, and species within genera, can be distinguished from each other by morphological characteristics of the pupae. In Table 1, Triorla spp. can be distinguished from Mallophora spp. by differences in the area around the prothoracic spiracles and in the number of bristles behind the spiracles of the first abdominal segment and ringlike anterior part of the eighth abdominal segment. $T$. striola can be separated from $T$. interrupta by use of the last two characteristics and by the number of dorsal spines on the first abdominal segment. The six species of Mallophora can be divided into two groups on the basis of (1) prothoracic spiracles on an upraised area and all or some of the dorsal spines on the first abdominal segment expanded, broad, or sagittate basally ( $M$. ruficauda, M. sylverii, M. belzebul, M. bomboides); or (2) prothoracic spiracles almost flush with the cuticle and the dorsal spines on the first abdominal segment not expanded, broad, or sag- ittate basally (M. fautrix, M. fautricoides, M. orcina). Within these two groups, ventral bristles and dorsal spines on the ringlike anterior part of the eighth abdominal segment can be used to separate species.

The pupae of the species of Diogmites can be divided initially into two groups on the basis of the presence $(D$. vulgaris, $D$. discolor) or absence $(D$. bilineatus, D. winthemi) of a space (or spaces) between the bristles on the ventral abdominal segments. Within these two groups, the presence or absence of a callosity on the labral sheath, number and shape of spines on the first abdominal segment, and number of lateral bristles on the ringlike anterior part of the eighth abdominal segment can be used to separate species.

\section{Key to Subfamilies of Asilidae on the Basis of Pupal Characters}

Recent studies of adult Asilidae have recognized four, five, or eight subfamilies. Martin (1968) recognized only four subfamilies (Asilinae, Dasypogoninae, Laphriinae, and Megapodinae) when he elevated the Leptogastrinae to family status. This separation was supported by Martin \& Papavero (1970) and by Papavero (1973). However, Oldroyd (1969) and Wood (1981) indicated that evidence was insufficient to separate the Leptogastrinae from the Asilidae.

Hull (1962) recognized five subfamilies of Asilidae (Asilinae, Dasypogoninae, Laphriinae, Leptogastrinae, and Megapodinae). Martin \& Wilcox (1965) and Wood (1981) followed Hull's (1962) classification with the exception of the Megapodinae, which are not found north of Mexico.

As indicated, Papavero (1973) considered the Leptogastrinae a separate family from the Asilidae. Papavero (1973) also provided a tentative subfamily classification of adult Asilidae into eight subfam- 
ilies (Apocleinae, Asilinae, Dasypogoninae, Laphriinae, Laphystiinae, Ommatiinae, Stenopogoninae, and Trigonomiminae). Knutson (1976) noted that Papavero's classification is probably a better arrangement than those of previous authors because of phylogenetic considerations and the worldwide scope of his study.

Although we recognize the importance of the controversy of the classification of adult asilids at the subfamily level, the traditional five-subfamily classification system seems most useful in terms of pupal characters. In part, this may be because information on the pupae of asilids is lacking. The subfamily key presented here recognizes five subfamilies and is a modification of the key presented by Knutson (1976).

1. Head with antennal processes which are truncate callosities or tuberclelike with a ridge, or short and acuminate; posterior antennal processes callosity-tuberclelike, palmateshaped or with a ridge; abdominal segments dorsally with anterior short spines and posterior hairlike processes (bristles) which are longer than the length of each segment; abdomen laterally and ventrally also with hairlike processes longer than length of each segment; dorsum of thorax with 4 bristles forming the corners of a square; last abdominal segment with 1 pair of terminal processes ..... Leptogastrinae

Head with distinct long, acuminate anterior antennal processes; posterior antennal processes present and not palmate or callositytuberclelike; abdominal segments dorsally with spines and not long hairlike processes; abdomen laterally and ventrally with short bristles (shorter than length of each segment); dorsum of thorax with or without 2-4 bristles; last abdominal segment with 2-6 pairs of processes ............. 2

2. Dorsal antennal processes present; anterior antennal processes almost straight; without anterior or posterior mesothoracic spines but with posterior mesothoracic callosity; with suborbital spines and medial facial spines ............... Megapodinae

Dorsal antennal processes absent; anterior antennal processes somewhat curved ventrad; with anterior or posterior mesothoracic spines or both; without suborbital spines, with or without medial or lateral facial spines .................... 3

3. Lower facial area with small medial or lateral spines; posterior antennal processes each usually with 3-5 confluent hooks; tapered portion of eighth abdominal segment usually with ventrolateral processes larger or broader than dorsolateral processes

Laphriinae

Lower facial area without medial or lateral spines; posterior antennal processes usually with only 3 confluent hooks, if more, hooks very long and narrow (some Dasypogoninae with 4 or 5 hooks); tapered posterior portion of eighth abdominal segment with ventrolateral processes smaller than dorsolateral processes .............. 4

4. Tapered posterior portion of eighth abdominal segment with dorsolateral and ventrolateral processes, and midventral callosities which are usually not tuberclelike; dorsolateral and ventrolateral processes pointed or curved dorsally ........ Dasypogoninae

Tapered posterior portion of eighth abdominal segment with dorsolateral and ventrolateral processes, and midventral callosities, if present, usually tuberclelike with dark sclerotized apex; dorsolateral processes may be curved or pointed dorsally, but ventrolateral processes generally point ventrally or in the opposite direction ....... Asilinae

\section{Acknowledgment}

We thank Mary Lou Cooley and Linda Lawrence (USDA-ARS, Systematic Entomology Laboratory [SEL]) for the illustrations; A. Scarbrough (Towson State University), W. L. Murphy, R. J. Gagné, D. R. Miller, and A. L. Norrbom (SEL) for reviewing the manuscript; $F$. C. Thompson (SEL) for extensive comments on an early draft of the manuscript; and R. F. Moore and D. Coutinot, (USDA-ARS, European Parasite Laboratory) for copies of biological notes and voucher specimens from studies carried out by H. C. Parker and other personnel of the South American Parasite Laboratory.

\section{References Cited}

Artigas, J. N. 1970. Los asilidos de Chile (DipteraAsilidae). Gayana, Zoologia 17: 1-473.

Artigas, J. N. \& A. O. Angulo. 1980. Revision del genero Mallophora Macquart por sistemática alfa y taxonomía numérica (Diptera-Asilidae). Gayana Zoologia 43: 1-182.

Bromley, S. W. 1946. Guide to the insects of Connecticut. Part VI. The Diptera or true flies of Connecticut. Third fascicle. Asilidae. Bulletin Connecticut Geological and Natural History Survey. 69.

Clements, A. N. \& F. D. Bennett. 1969. The structure and biology of a new species of Mallophora Macq. (Diptera, Asilidae) from Trinidad, W.I. Bull. Entomol. Res. 58: 455-463.

Copello, A. 1927. Biología del Moscardón cazador de abejas (Mallophora ruficauda Wied.). Argentina Ministerio Agricultura, Sección Propaganda e Informes, Circular 699

1942. Moscardón cazador de abejas "Mallophora Ruficauda." Rev. Apicultura, Argentina 19(200): 1314; (218): 4-5; (219): 10-11; (221): 14; (222): 12-13.

Davis, J. J. 1919. Contributions to a knowledge of the natural enemies of Phyllophaga. Ill. Nat. Hist. Surv. Bull. 13: 53-138, pls. III-XV.

Hull, F. M. 1962. Robber flies of the world. The genera of the family Asilidae. Bull. U.S. Natl. Mus. 224: 1-430 (pt. 1), 431-907 (pt. 2).

Knutson, L. 1972. Pupa of Neomochtherus augustipennis (Hine), with notes on feeding habits of robber flies and a review of publications on morphology 
of immature stages (Diptera: Asilidae). Proc. Biol. Soc. Wash. 85: 163-178.

1976. Key to subfamilies of robber flies based on pupal cases, with a description of the pupal case of Doryclus distendens (Asilidae: Megapodinae). Proc. Biol. Soc. Wash. 88: 509-514

Lavigne, R., S. Dennis \& J. A. Gowen. 1978. Asilid literature update, 1956-1976, including a brief review of robber fly biology (Diptera: Asilidae). University of Wyoming Agricultural Experiment Station Scientific Monograph, 36.

Malloch, J. R. 1915. Some additional records of Chironomidae for Illinois and notes on other Illinois Diptera. Bull. Ill. State Lab. Nat. Hist. 11: 305-363, pls. 80-84.

1917. A preliminary classification of Diptera, exclusive of Puparia, based upon larval and pupal characters, with keys to imagines in certain families. Part 1. Bull. Ill. State Lab. Nat. Hist. 12: 161-409, pls. 2857.

Martin, C. H. 1968. The new family Leptogastridae (the grass flies) compared with the Asilidae (robber flies) (Diptera). J. Kans. Entomol. Soc. 41: 70-100.

Martin, C. H. \& N. Papavero. 1970. Family Asilidae, pp. 1-139. In A Catalogue of the Diptera of the Americas South of the United States. Museu de Zoologia, Universidade São Paulo.

Martin, C. H. \& J. Wilcox. 1965. Family Asilidae, pp. 360-401. In A. Stone et al. [eds.], A catalog of the Diptera of America north of Mexico. USDA-ARS, Agriculture Handbook 276.

Melin, D. 1923. Contributions to the knowledge of the biology, metamorphosis, and distribution of the Swedish asilids in relation to the whole family of asilids. Zool. Bidr. Upps. 8: 1-317.

Oldroyd, H. 1969. The family Leptogastridae (Diptera). Proc. Entomol. Soc. Lond. (B) 38: 27-31.

Osterberger, B. A. 1930. Erax interruptus Macq. as a predator. J. Econ. Entomol. 23: 709-711.

Papavero, N. 1973. Studies of Asilidae (Diptera) systematics and evolution. I. A preliminary classification in subfamilies. Arq. Zool. (São Paulo) 23: 217-274.

1975. Studies of Asilidae (Diptera) systematics and evolution. IV. Tribe Megapodini Carrera (Dasypogoninae), with a review of the Neotropical species. Arq. Zool. (São Paulo) 26: 191-318.

Parker, H. L., P. A. Berry \& A. Silveira Guido. 1953. Host-parasite and parasite-host lists of insects reared in the South American Parasite Laboratory during the period 1940-1946. Revista de la Asociación de Ingenerios Agrónomos 92.

Parks, L. 1968. Synopsis of robberfly genera allied to Efferia and Eicherax including a new genus. PanPac. Entomol. 44: 171-179.

Skidmore, P. 1960. Asilidae (Diptera) of northern England. Entomol. Rec. J. Var. 78: 230-235, 257266.

Wood, G. C. 1981. Asilidae, pp. 549-573. In J. F. McAlpine et al. [eds.], Manual of Nearctic Diptera, vol. 1. Research Branch, Agriculture Canada, Monograph 27.

Received for publication 16 July 1987; accepted 24 May 1988. 